\title{
Design Factors of Ngembul Spring Water Tourism Development for Conserving the Green Belt of Tajinan, Malang
}

\author{
Subhan Ramdlani ${ }^{1}$, Ariza Rufaida ${ }^{2 *}$ \\ ${ }^{1,2}$ Department of Architecture, Faculty of Engineering, Universitas Brawijaya, Malang, Indonesia \\ *Corresponding author. Email: arizarufaidah44@gmail.com
}

\begin{abstract}
Community-based tourism is now being developed on many lands belonging to the village community or owned by the government, which are considered capable of involving the community in planning, management, and decision making in their development. Ngembul Spring Water (NSW) is spring water surrounded by the green belt, which has the potential to develop as community-based tourism in Tajinan. There are various design factors to develop it, including three main factors, namely attraction, accessibilities, and accommodation. Community preferences are also needed to determine the design factors of tourism development. Primary data was collected through in-depth interviews, field observations, and questionnaires. Then, it is analyzed by qualitative methods, namely explanatory, to explain the actual conditions of the field. Furthermore, quantitatively the results are analyzed by factor analysis. From the factor analysis, seven design factors emerged, which could determine the priority elements in tourism development. The preference factors are essential for developing the direction of community-based tourism development while conserving the green belt.
\end{abstract}

Keywords: Design factors, tourism, conservation

\section{INTRODUCTION}

Ngembul Water Source (NWS) in Tajinan, Malang Regency, is one of the main clean water sources for the Greater Malang area. While serving the supply of clean water for the Greater Malang area, at the same time, villagers often utilize NWS as a tourist destination. NWS is registered as an area with potential development of natural and artificial tourism in the Malang Regency. NWS, with a water discharge of $7.31 \mathrm{l} / \mathrm{s}$, is considered ready to be developed as a water tourism destination while supplying clean water. This destination will be developed bottom-up, by a community-based or village head initiative and full support of the local community. If the NWS is developed as a tourist destination that involves community participation, then it should also consider the preferences of the community as users and prospective managers who live around the NWS.

The community participation has initially been seen as a discussion or consultancy between the local people and the local government based on the Skeffington Report in 1969 [1]. Nevertheless, Litchfield [2] said it is a comprehensive participation only when there is complete participation by the locals in the planning procedure. World Bank also discusses that public involvement is not only about the affiliation between the local government and the local community, but it is an authorization process given to the local community for decision making [3]. Furthermore, the view of the locals must be taken into consideration so that it will aid attain a worthy decision-making process and manage resources competently and effectively [4].

Tosun [5] in his study believed that by having participatory approach would enable employment of principles of sustainable tourism by producing enhanced opportunities for local residents to gain larger and more balanced benefits from tourism which is taking place in their areas, which will subsequently lead to positive attitudes to in conserving the local resources and nature.

NSW has a slope of $9,39 \%$, which belongs to the ramps and rises on the east side. The type of soil on the site is an association of brown latosol soil types that can absorb water well, are very fertile, and soft in texture, and gray regosol which is included in the combined category for a long time absorbing water, so the water will stagnate first for a certain time. Finally, rainfall in NSW ranges between $45 \mathrm{~mm}-62.8$ $\mathrm{mm}$, which is included in the very high category. From the results of the calculation, the total site score reaches 140 and falls into the category of an area with a buffer function (green belt) [6].

The location of NSW in the highlands causes the vegetation pattern to be the same as the vegetation pattern in other highlands on Java Island. It is quite diverse. It is ranging from secondary crops to forest types in the form of shrubs, shrubs, trees, and grasses. Vegetation is the main element of ecological functions that fulfill the comfort of the site. The pattern of distribution of vegetation tends to colonizesimilar vegetation cluster held in an area on the site.

As for wildlife, a brief observation of wildlife in NSW found wildlife that is often found in forest ecosystems, 
rivers, and rice ecosystems. For water retention, there is a reservoir that holds water from a water source but can also hold rainwater. From the reservoir, water flows directly into the Ngembulsari river. That is all local resources and nature to balance the environment of NSW.

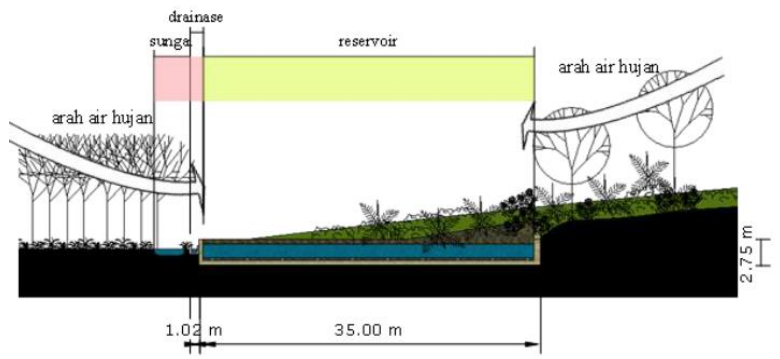

Figure 1 The reservoir and the river on site

\section{LITERATURE REVIEW}

In tourism, three components become the main conditions for an area to be used as a tourist destination. Those are the most important factor to attract tourists towards a destination [7]. The three components are the attraction, accessibility, accommodation, and amenities. Attraction divided into three kind attraction: natural attraction, human- made attraction, and cultural attraction. Accessibility is the way to reach the destination. The accommodation has two types: serviced accommodation and self-catering and supplementary accommodation.

The concept of developing natural tourism always focuses on the relationship between the protection or preservation of nature with the tourism industry. Therefore, the development of a natural tourism object is divided into several areas [8]: a. Special areas, namely areas that are protected and not open to the public.; b. Wilderness recreation areas, namely areas that have limited access; c. Natural environment areas, areas that can be visited by tourists but are limited in the development of facilities; $\mathrm{d}$. General outdoor recreation areas, planned recreation areas; and e. Intensive use areas, areas that are the main service areas for tourism.

Table 1 shows a summary of the design factors that have been learned in other studies. Although there are many studies related to the development of nature tourism with components of tourism and the potential factor to develop, only a few studies deal with the goals of conservation of the green buffer landscape. The design factors can be divided into four categories with sub-parameters. The effective design factors influence landscape preservation as well as green belt. Therefore, layout types such as local and public facilities were not statistically significant.

Table 1 A summary of influential design factors for conservation landscape based on literature reviews.

\begin{tabular}{|l|l|l|}
\hline \multicolumn{1}{|c|}{ Authors } & \multicolumn{1}{c|}{ Design factors } & \multicolumn{1}{c|}{ Variables } \\
\hline Inskeep [7] & Components of Tourism & - Attraction \\
& & - Accessibility \\
& & - Accommodation \\
\hline $\begin{array}{l}\text { Ministry of Agriculture, } \\
\text { Republic of Indonesia } \\
{[9,10]}\end{array}$ & Physical Feasibility & - Slope / Slope \\
\hline Hakim [11] & & - Types of soil \\
& Components of Landscape & - Rainfall \\
\hline Gunn [8] & - Hardscapes \\
& Areas of Natural attraction & - Special areas, \\
& & - Wilderness recreation areas, \\
& & - Natural environment areas. \\
& & - General outdoor recreation areas, \\
& & - Intensive use areas \\
\hline
\end{tabular}

\section{METHODOLOGY}

The method that will be used in this research is a combination or mixed-method, which is a combination of qualitative and quantitative descriptive methods. Descriptive research is used to provide an accurate picture of a phenomenon or phenomenon that is happening [12]. While quantitative research is a research approach in which data is in the form of numbers and analyzed with statistics [13]. Explanatory methods are also used to identify and explain data obtained in the field. Then, the data will be reviewed based on relevant theory, standards, government regulations, and previous studies. Quantitative methods are used to analyze the preference questionnaire data of the community of Randugading Village in the development of tourism at NSW.

The research instrument used for qualitative research is in the form of direct observation of the field by documenting the existing conditions on the research object to determine what factors need to be addressed in the development of tourism in NSW. The tools used in field observations are cameras, drones, stationery, meters, and recorders for interviews. Then for the quantitative research data, questionnaires were distributed to the people of Rambaan Hamlet.

The population in this study is the population of Rambaan Hamlet, amounting to 1,832 residents based on data from the Randugading Village Hall. Rambaan Hamlet is the 
leading hamlet in Randugading Village, where most of the people have a superior level of education among other hamlets in Randugading Village. Sample selection is based on a sample that has a purpose and is considered to represent a generally homogeneous population [13]. The sample in this study were residents of Rambaan Hamlets. The selection of this sample is based on the main user of NSW tourism, namely the Randugading village community, whose consideration is needed for the development of tourism at NSW with a simple random sampling system.

Based on the results of calculations with the Slovin formula, it is known that the total population of 1,832 residents, then produced a total sample of 94.8 respondents who then rounded up to 100 respondents. Data collection methods used were field observations, interviews, and questionnaires for primary data. For secondary data, the data collection method uses literature, government regulations, and related institutions/agencies.
In qualitative analysis, the data will be analyzed with a descriptive approach. Descriptive research aims to describe or describe a phenomenon [14]. In this study, the phenomenon that will be described is the actual condition of the NSW site. Furthermore, the method for analyzing quantitative data is factor analysis with SPSS. However, before entering the factor analysis stage, a validity and reliability test is performed to determine whether all subvariables are eligible for further analysis using factor analysis. After that, a normality test is also conducted to test whether the data are normally distributed or not. In the factor analysis in this study, there are two main stages, namely the factor independence test and factor extraction. Summary of the influence design factor breaks down to some variables, sub-variables, and some indicators (Table 2).

Table 2 Variables and indicators.

\begin{tabular}{|c|c|c|}
\hline Variables & Sub variables & Indicators \\
\hline \multirow{8}{*}{ Attraction } & \multirow[t]{3}{*}{ Natural attraction } & Maintained water reservoir \\
\hline & & Protecting Fishing ponds \\
\hline & & Preserving Outbound \\
\hline & \multirow[t]{4}{*}{ Man-made Attraction } & Bathing pools activities \\
\hline & & Camping ground availability \\
\hline & & Jogging track activities \\
\hline & & Souvenir counters activities \\
\hline & Cultural attraction & Local art and cultural stage performances availability \\
\hline \multirow[t]{3}{*}{ Accessibility } & Access in and out of the tourist area & Accessible \\
\hline & Access to tourist attractions & Reachable \\
\hline & Access to tourist facilities & Economical and environmentally friendly material \\
\hline \multirow[t]{2}{*}{ Accommodation } & Serviced accommodation & $\begin{array}{l}\text { - Comfortable } \\
\text { - Placement of facilities takes into account the criteria of a protected water source area } \\
\text { - Pay attention to carrying capacity in certain areas } \\
\text { Availability of facilities that meet architectural standards. }\end{array}$ \\
\hline & $\begin{array}{l}\text { Self-catering and supplementary } \\
\text { accommodation }\end{array}$ & Healthy and environmentally friendly material \\
\hline \multirow{7}{*}{$\begin{array}{l}\text { Hardscapes and } \\
\text { softscapes }\end{array}$} & Pedestrian & Comfortable and safety \\
\hline & Trees along the path & Shady trees \\
\hline & Adequate drainage & Capacity for drain \\
\hline & The existence of lighting & Lighting capacity \\
\hline & Rubbish bins & Placement and distribution \\
\hline & Park benches (garden furniture) & Economical and environmentally friendly material \\
\hline & Shelter & Accordance with the principles of structuring outdoor space \\
\hline \multirow{5}{*}{$\begin{array}{l}\text { Areas of natural } \\
\text { attraction }\end{array}$} & Special areas & Protected and not open to the public. \\
\hline & Wilderness recreation areas & Limited access \\
\hline & Natural environment areas & Visited by tourists but are limited in the development of facilities \\
\hline & General outdoor recreation areas & Planned recreation areas \\
\hline & Intensive use areas & Main service areas for tourism. \\
\hline
\end{tabular}




\section{RESULT AND DISCUSSION}

\subsection{Analysis of the Tourism Component}

The existence of tourist attractions in NSW is indicated by some indicators as follows:

- The maintained water reservoir. This reservoir is an area that should not be used for bathing or fishing. Nevertheless, the reservoir must still be beautified to create a view for other attractions.

- Availability of bathing pools. Bathing pool tourism needs to be immediately completed because it is one of the attractions that are in great demand.

- Availability of fishing ponds. The existence of fishing ponds is also one of the activities in the NSW tourism attraction.

- Availability of local art and cultural performance stages. The stage can be made simply with local materials that can be permanent or semi-permanent.

- Natural scenery. The natural scenery is maximized in the resting area where this area is at a higher altitude than the other plains with a view towards the rice fields and water sources.

- Availability of camping ground. Camping ground can be made on flat land in the area around the pavilion.

- Availability of outbound facilities. Steep contour differences can be utilized as an area for outbound with a potential view towards water sources.

- Availability of jogging track. The jogging track is currently still one with the pedestrian lane, so it needs a division of lanes in the form of material differences or markers.

- Gate. Currently, in actual conditions, there are counters at the entry point to the site. However, no gate characterizes the entrance to a tourist destination, for that we need an attractive gate but still in harmony with nature and made with natural materials to strengthen the image.

While the analysis of the availability of accommodation in NSW is indicated as follows:

- The availability of homestay accommodation facilities. Homestay built in the water source area does not yet exist, but around the site, there is already a homestay. Homestay should be built close to other facilities to make it easier for tourists.

- Availability of clinics. Some clinics are already outside the site, so that they are not prioritized.

- Availability of public facilities for worship/ prayer rooms. In the current situation, the musholla (small mosque) is in front of the entrance of the water source, even though the location is outside the site. The mosque does not have a high urgency to develop first, but an informative marker is still needed from the exit of the water source to the mosque.

- Availability of restaurant facilities. At NSW, it requires the availability of permanent restaurants to facilitate tourists and also as a place for employment for the surrounding community.

- Availability of public toilets and lockers. The existence of toilets is essential because it is not yet available on the site. Toilets and lockers can be built permanent because they are primary facilities.

- Availability of souvenir/ gift shops. At NSW, there is no place for people to sell or buy souvenirs or local crafts. So that its availability falls into the category most needed

- Availability of a resting area. It can be made in the form of small shades with garden furniture or with a large gazebo to be a visitor resting area. The site is available, but the situation is still not optimal.

- The availability of tourist parking lots. It is already available on the site and includes two or four-wheeled vehicles, but parking spaces require completion because there are no markers. Hence, the direction of vehicle parking is still not in order.

Access to NSW can be said to be sufficient. The road is quite wide, around 2 meters, and can be passed by fourwheeled vehicles, but only in one direction. When entering into the residential road, the road becomes narrower but still fit by four-wheeled vehicles. The most common mode of transportation there is a motorcycle. There are no clear markers on how to get to NSW, so it is quite difficult to find the location if without asking the surrounding population.

\subsection{Physical Environmental Analysis (Hardscapes and Softscapes)}

- The comfortable and safe place to walk; where the pedestrian paths are made with material that is safe when dry or rainy and can absorb rainwater so that pedestrians feel safe and comfortable and do not interfere with the absorption of rainwater

- Shady trees along the path, lush areas in NSW are still around the reservoir. The vegetation is still maintained because they are advantageous for the continuity of NSW. However, in areas that are quite busy with activities, it is necessary to plant shade trees so that visitors still feel comfortable.

- The existence of informative markers on the site is still very minimal and needs to be corrected immediately to be more informative.

- The existence of lighting and information on the site now exists but still needs to be added in number.

- The availability of trash bins. Trash bins are not yet available in all areas; it is vital so that tourists and the public do not litter.

- Availability of park benches (garden furniture), needed are placed on the edge of the pedestrian path, this is intended as a resting place for visitors when walking.

- Shelter availability, can be combined with the presence of park benches or garden furniture. 
- Building materials in harmony with nature can be created through the use of local materials found around the site.

\subsection{Factor Analysis}

After the data of 28 variables passed through the instrument test and continued with MSA and KMO test, the analysis of communalities value was continued to see how many factors were formed. This analysis process is by selecting factors that have an eigenvalue $>1$ and have a cumulative percentage greater than $60 \%$. Factor extraction of the factors studied shows that there are seven factors formed by marked eigenvalues (in the total eigenvalues column) more than 1 . The factoring process stops at only seven factors because the number of eigenvalues below 1 is not used in calculating the number of factors formed.

Table 3 Communalities test results.

\begin{tabular}{|c|c|c|c|c|}
\hline \multirow[b]{2}{*}{ Component } & \multicolumn{3}{|c|}{ Initial Eigenvalues } & \multirow[b]{2}{*}{ Information } \\
\hline & $\begin{array}{c}\text { Total } \\
\text { Eigenvalue }\end{array}$ & $\begin{array}{l}\% \text { Total } \\
\text { diversity }\end{array}$ & $\begin{array}{c}\text { \% Cumulative } \\
\text { Diversity }\end{array}$ & \\
\hline Maintained water reservoir & 8.348 & 29.813 & 29.813 & Used \\
\hline Availability of fishing ponds & 3.095 & 11.054 & 40.867 & Used \\
\hline Availability of bathing pools & 1.839 & 6.568 & 47.435 & Used \\
\hline Availability of local art and cultural stage performance & 1.654 & 5.907 & 53.342 & Used \\
\hline Natural scenery & 1.453 & 2.190 & 53.531 & Used \\
\hline Availability of camping ground & 1.259 & 4.496 & 63.028 & Used \\
\hline Availability of Outbound facilities & 1.141 & 4.075 & 67.102 & Used \\
\hline Jogging track availability & 0.948 & 3.386 & 70.488 & - \\
\hline Availability of gates and counters & 0.911 & 3.252 & 73.741 & - \\
\hline Availability of homestay accommodation facilities & 0.838 & 2.993 & 76.733 & - \\
\hline Availability of clinics & 0.780 & 2.785 & 79.519 & - \\
\hline Availability of public facilities for places of worship/prayer rooms & 0.727 & 2.598 & 82.116 & - \\
\hline Availability of public restaurant / restaurant facilities & 0.613 & 2.188 & 84.304 & - \\
\hline Availability of public facilities public toilets and lockers & 0.516 & 1.843 & 86.147 & - \\
\hline Availability of souvenir/gift shops & 0.498 & 1.780 & 87.927 & - \\
\hline Rest area availability & 0.461 & 1.648 & 89.575 & - \\
\hline Availability of tourist parking lots & 0.436 & 1.556 & 91.130 & - \\
\hline Access in and out & 0.382 & 1.366 & 92.496 & - \\
\hline Access to tourist attractions & 0.364 & 1.301 & 93.797 & - \\
\hline Access to tourist facilities & 0.338 & 1.207 & 95.004 & - \\
\hline A comfortable and safe place to walk & 0.290 & 1.035 & 96.039 & - \\
\hline Shady trees along the path & 0.256 & 0.913 & 96.952 & - \\
\hline Adequate drainage & 0.239 & 0.853 & 97.805 & - \\
\hline The existence of lighting & 0.165 & 0.590 & 98.395 & - \\
\hline Availability of rubbish bins & 0.155 & 0.552 & 98.947 & - \\
\hline Availability of park benches (garden furniture) & 0.114 & 0.407 & 99.354 & - \\
\hline Shelter availability & 0.108 & 0.385 & 99.739 & - \\
\hline Building materials in harmony & 0.073 & 0.261 & 100.00 & - \\
\hline
\end{tabular}

After knowing that the seven factors are the most optimal number, the Rotation Component Matrix table shows the distribution of the 28 items on the seven factors formed. The loading factor in Table 4 shows the correlation between a variable with a factor of 1 to a factor of 7 .

Table 4 Factor extraction results.

\begin{tabular}{|c|c|c|c|}
\hline Factor & Variables & Loading Factor & \% variance \\
\hline \multirow[t]{8}{*}{ I } & Availability of public facilities public toilets and lockers & 0.795 & \multirow{8}{*}{29.813} \\
\hline & Availability of tourist parking lots & 0.710 & \\
\hline & Availability of restaurant facilities & 0.668 & \\
\hline & Availability of park benches (garden furniture) & 0.598 & \\
\hline & Shelter availability & 0.583 & \\
\hline & Availability of souvenir/gift shops & 0.581 & \\
\hline & Jogging track availability & 0.574 & \\
\hline & Availability of gates and counters & 0.517 & \\
\hline \multirow[t]{2}{*}{ II } & Availability of bathing pools & 0.890 & \multirow{2}{*}{11.054} \\
\hline & Availability of local art and cultural stage performances & 0.883 & \\
\hline
\end{tabular}




\begin{tabular}{|c|c|c|c|}
\hline Factor & Variables & Loading Factor & $\%$ variance \\
\hline & A comfortable and safe place to walk & 0.774 & \\
\hline & Building materials in harmony & 0.541 & \\
\hline & Rest area availability & 0.478 & \\
\hline \multirow[t]{3}{*}{ III } & Availability of trash & 0.773 & \multirow{3}{*}{6.568} \\
\hline & Access to tourist facilities & 0.716 & \\
\hline & Access to tourist attractions & 0.408 & \\
\hline \multirow[t]{3}{*}{ IV } & Availability of fishing ponds & 0.679 & \multirow{3}{*}{5.907} \\
\hline & Availability of homestay accommodation facilities & 0.672 & \\
\hline & Maintained water reservoir & 0.600 & \\
\hline \multirow[t]{3}{*}{$\mathrm{V}$} & Shady trees along the path & 0.799 & \multirow{3}{*}{5.190} \\
\hline & The presence of informative markers & 0.781 & \\
\hline & The existence of lighting & 0.799 & \\
\hline \multirow[t]{3}{*}{ VI } & Availability of camping ground & 0.767 & \multirow{3}{*}{4.496} \\
\hline & Natural Scenery & 0.545 & \\
\hline & Outbound facilities available & 0.538 & \\
\hline \multirow[t]{3}{*}{ VII } & Availability of public facilities for worship/ prayer rooms. & 0.771 & \multirow{3}{*}{4.075} \\
\hline & Availability of clinics & 0.580 & \\
\hline & Access in and out of the tourist area & 0.487 & \\
\hline
\end{tabular}

Based on the extraction and rotation of factors, seven new factors were formed that could determine the priority elements determined based on their weight in the development of NSW tourism in terms of their contribution weight. Naming factors in terms of the biggest factor loading weights on each factor. Besides, in naming the factors, also consider the members of the group forming the factors. The naming or interpretation of factors aims to interpret or translate the extraction results so that they can be easily understood as a reference in developing NSW tourism. The interpretation of the seven new factors that are taken into consideration in developing NSW tourism will be described as below:

a. Factor I, Main Amenity Tourism with a contribution weight of $29,813 \%$ to the development of NSW tourism.

b. Factor II, Cultural Tourism with a contribution weight of $11,054 \%$ to the development of NSW tourism.

c. Factor III, Accessibility in the Site with a contribution weight of $6,568 \%$ to the development of NSW tourism.

d. Factor IV, Water Recreation, which contributes a weight of $5,907 \%$ to the development of NSW tourism.

e. Factor V, Completeness of Landscape Elements, which contributes a weight of $5,190 \%$ to the development of NSW tourism.

f. Factor VI, Ecological / Nature Tourism with a contribution weight of $4,496 \%$ to the development of NSW tourism.

g. Factor VII, Supporting Tourism Amenity with a contribution weight of $4.075 \%$ towards the development of NSW tourism.

\section{CONCLUSION}

In terms of supply for the tourism component aspect at NWS, the site has the potential to develop three types of attractions, namely natural attractions, cultural attractions, and Man-made attractions. However, facilities are still very minimal, so development is needed by considering environmental and community aspects. The accessibility to the site is in good condition. However, the accessibility in the site still needs development. On the environmental aspect, the development must consider the biophysical conditions of the site that fall into the land classification with a buffer function. In the results of the analysis based on factor analysis, seven new factors were formed that could determine the priority elements in the development of NSW tourism in terms of the weight of its contribution.

\section{REFERENCES}

[1] Great Britain Committee on Public Participation in Planning. People and Planning: Report of the Committee on Public Participation in Planning (the Skeffington Report). London: HMSO, 1969.

[2] Lichfield, N. Community Impact Evaluation. London: UCL Press, 1996.

[3] World BankWorld Bank Participation Sourcebook, Environment Department Papers Participation Series. Washington DC: World Bank, 1995.

[4] WHO, Regional Office for Europe Community participation in local health and sustainable development: approaches and techniques. Copenhagen: WHO Regional Office for Europe: WHO, 2002.

[5] Tosun, C. Expected nature of community participation in tourism development. Tourism Management 27 (3) (2006) 493-504.

[6] Ramdlani, S. Ngembul Water Development Plan, Ngembulsari Hamlet, Randugading Village, Tajinan District, Malang Regency. Malang: BPP FTUB, 2016. 
[7] Inskeep, E. Tourism planning: an integrated and sustainable development approach. New York: Van Nostrand Reinhold, 1991.

[8] Gunn, CA. Tourism Planning: Basics, Concepts, Cases, Third Edition. Taylor \& Francis, Journal of Travel Research, vol. 32, no. 3 (1994). doi:10.1177/004728759403200371.

[9] Surat Keputusan Menteri Pertanian. Nomor: 837/Kpts/Um/11/1980 tentang Kriteria dan Tata Cara Penetapan Hutan Lindung

[10] Surat Keputusan Menteri Pertanian. Nomor: 683/Kpts/Um/8/1981 Tanggal 8 Agustus 1981 tentang Kriteria dan Tata Cara Penetapan Hutan Produksi.

[11] Hakim, Rustam. Hardi Utomo. Komponen Perancangan Arsitektur Lansekap. Jakarta: Bumi Aksara, 2003.

[12] Koentjaraningrat. Metode-Metode Penelitian Masyarakat. Jakarta: PT. Gramedia, 1993.

[13] Sugiyono. Statistika Untuk Penelitian Kuantitatif, Kualitatif dan R\&D. Cetakan Ketujuh. Bandung: CV Alfabeta, 2006.

[14] Kotler, P. Manajemen Pemasaran. Jilid I. Jakarta: PT. Gramedia, 2006. 